\title{
A Nine Case Series of Ultrasound-Guided Hydrostatic Reduction of Intussusception by Saline Enema
}

\author{
Sornsupha Limchareon ${ }^{1}$, Adisorn Boonyarit ${ }^{2}$ \\ ${ }^{1}$ Division of Radiology and Nuclear Medicine, Faculty of Medicine, Burapha University, Chonburi, Thailand \\ ${ }^{2}$ Department of Radiology, Phyathai-Sriracha Hospital, Chonburi, Thailand
}

\begin{abstract}
Non-surgical reduction of the intussusception is the first line treatment in children with intussusception. Among various radiological reduction techniques, barium enema reduction of the intussusception under fluoroscopy has been widely used in Thailand while pneumatic reduction under fluoroscopy has become popular in teaching hospitals. To our knowledge, ultrasound-guided hydrostatic reduction of the intussusception by saline enema (UGHSE) has never been used in Thailand. We reported 9 cases using UGHSE with $100 \%$ success rate without complication.
\end{abstract}




\section{Introduction}

Intussusception is the invagination of one bowel segment into the lumen of the other. It is a common cause of the intestinal obstruction in infants and children. It frequently occurs in well-nourished infants, mostly are 4 to 12 months old ${ }^{1}$. The majority of the causes are idiopathic ${ }^{2}$. The remaining causes are the pathologic lead points such as polyp, Meckel's diverticulum, duplication cyst ${ }^{1,2}$. US is the modality of choice for the diagnosis of intussusception ${ }^{3}$. The traditionally barium enema was used to diagnose and reduction of intussusception ${ }^{1}$. If the attempt of reduction was failed, surgery was subsequently indicated. There have been various techniques mentioned in the literature that improved the success rate and less perforation rate ${ }^{4-6}$. The advantages and disadvantages of each technique has been discussed ${ }^{2,4-6}$. The technique of radiological reduction in daily practice depends on the radiologist's preferences ${ }^{7}$. In Thailand barium enema reduction of intussusception under fluoroscopy has been widely used and pneumatic reduction under fluoroscopy is popular in teaching hospitals, while UGHSE has never been used.

\section{Case series}

From January 1, 2011 to July 31, 2013, we performed UGHSE in 9 children. The detail of each patient is shown in table 1 . There were 5 boys and 4 girls, aged 4-36 months (average 19.6 months). All except one patient had no fever on the presentation. The most common symptom was abdominal pain (56\%), followed by fever (44\%), vomiting (33\%), diarrhea (22\%), and bloody stool (22\%). The maximum duration of the symptoms was 6 days,average 2.28 days. Seven out of 9 nine $(78 \%)$ patients had negative physical examinations. White blood count was done in 8 patients. All of them showed no leukocytosis or neutrophil shift. Five patients had abdominal radiographs but intussusception was suspected in only two (22\%). All the intussusceptions was diagnosed by US, showing target sign in short-axis view. The most common locations of the intussusception apices was hepatic flexure in 7 (78\%).

The average axial diameter of the intussusception was $2.41 \mathrm{~cm}$ (range 1.9-3.2 cm). Reduction was successful by the first attempt in 7 of $9(78 \%)$ and the second attempt in 2 (22\%). All children was free from complication or recurrence in at least 48-hour follow up.

\section{Technique}

We informed parents, pediatricians with/or without surgeons before the procedure. The procedure was performed in the US room. An enema bag was filled with $1,000 \mathrm{ml}$ of normal saline that was warmed at the temperature of $37^{\circ} \mathrm{C}$ and was kept at $100-120 \mathrm{~cm}$ above the table top. The upper end of the saline bag remained open. A well-lubricated Foley's catheter (12-16 F was introduced transrectally) with balloon inflation. The buttocks was firmly taped together with adhesive tape and by manually during the procedure. No sedation, muscle relaxant or prophylaxis antibiotic was administered. The reduction was observed under the guidance of US by using a $5-12 \mathrm{MHz}$ linear transducer (Toshiba Aplio, XG SSA-790A, Japan). Successful reduction was determined when the IC valve and terminal ileum were visualized associated with fluid reflux into the small bowel. During the reduction, we intermittently observed US findings of perforation including sudden collapse of the colon, and rapid increased intraperitoneal free fluid. 
Table 1. Details of 9 patients.

\begin{tabular}{|c|c|c|c|c|c|c|c|c|c|}
\hline $\begin{array}{l}\text { Case } \\
\text { No. }\end{array}$ & Sex & $\begin{array}{l}\text { Age } \\
\text { (mo) }\end{array}$ & Symptoms & $\begin{array}{l}\text { BT } \\
\left({ }^{\circ} \mathrm{C}\right)\end{array}$ & $\begin{array}{l}\text { PE- } \\
\text { abdo } \\
\text { men }\end{array}$ & WBC/N & Abd film & $\begin{array}{l}\text { US intus } \\
\text { location+ } \\
\text { size }\end{array}$ & $\begin{array}{l}\text { Successful } \\
\text { reduction }\end{array}$ \\
\hline 1 & $M$ & 5 & $\begin{array}{l}\text { Fever+ } \\
\text { vomiting } 1 \text { day }\end{array}$ & 36.9 & neg & $\begin{array}{l}14600 \\
\text { ( N } 59, \\
\text { L39, Mo } \\
\text { 2) }\end{array}$ & $\begin{array}{l}\text { Suspected } \\
\text { mass at } \\
\text { RUQ }\end{array}$ & $\begin{array}{l}\text { Hepatic } \\
\text { flexure } \\
2.1 \mathrm{~cm}\end{array}$ & $1^{\text {st }}$ attempt \\
\hline 2 & $M$ & 34 & $\begin{array}{l}\text { Abdominal } \\
\text { pain } 9 \text { hours }\end{array}$ & 36.1 & $\begin{array}{l}\text { Mass } \\
?\end{array}$ & $\begin{array}{l}8900 \\
\text { (N } 42 \text { L } 47 \\
\text { Mo 11) }\end{array}$ & - & $\begin{array}{l}\text { Mid } \\
\text { ascend } \\
2.2 \mathrm{~cm}\end{array}$ & $1^{\text {st }}$ attempt \\
\hline 3 & $\mathrm{~F}$ & 4 & $\begin{array}{l}\text { Fever } 3 \text { days, } \\
\text { Bloody stool + } \\
\text { vomiting } 1 \text { day }\end{array}$ & 36.9 & neg & $\begin{array}{l}3800 \\
\text { (N } 60 \text { L } 32 \\
\text { Mo } 7 \text { ) }\end{array}$ & $\begin{array}{l}\text { Unremark- } \\
\text { able }\end{array}$ & $\begin{array}{l}\text { rectosig } \\
\text { moid }\end{array}$ & $1^{\text {st }}$ attempt \\
\hline 4 & $M$ & 25 & $\begin{array}{l}\text { Abdominal } \\
\text { pain } 1 \text { day }\end{array}$ & 37.2 & neg & $\begin{array}{l}5500 \\
(N 73 \text { L } 23 \\
\text { Mo 3 ) }\end{array}$ & - & $\begin{array}{l}\text { Hepatic } \\
\text { flexure } \\
2.1 \mathrm{~cm}\end{array}$ & $1^{\text {st }}$ attempt \\
\hline 5 & $M$ & 36 & $\begin{array}{l}\text { Abdominal } \\
\text { pain } 4 \text { days }\end{array}$ & 36.0 & neg & $\begin{array}{l}10300(\mathrm{~N} \\
49 \mathrm{~L} 47 \\
\text { Mo 3) }\end{array}$ & - & $\begin{array}{l}\text { Hepatic } \\
\text { flexure } \\
3.1 \mathrm{~cm}\end{array}$ & $1^{\text {st }}$ attempt \\
\hline 6 & $\mathrm{~F}$ & 26 & $\begin{array}{l}\text { Abdominal } \\
\text { pain + vomiting } \\
2 \text { days, } \\
\text { diarrhea ? day }\end{array}$ & 37.0 & neg & $\begin{array}{l}11600 \\
\text { (N } 46 \text { L } 51 \\
\text { Mo } 3 \text { ) }\end{array}$ & $\begin{array}{l}\text { Suggestive } \\
\text { of } \\
\text { intussucep- } \\
\text { tion }\end{array}$ & $\begin{array}{l}\text { Hepatic } \\
\text { flexure } \\
2.7 \mathrm{~cm}\end{array}$ & $1^{\text {st }}$ attempt \\
\hline 7 & $M$ & 10 & $\begin{array}{l}\text { Abdominal } \\
\text { pain } 1 \text { day }\end{array}$ & 36.5 & neg & $\begin{array}{l}9400 \\
\text { (N } 54 \text { L } 39 \\
\text { Mo } 7 \text { ) }\end{array}$ & - & $\begin{array}{l}\text { Hepatic } \\
\text { flexure } \\
2.1 \mathrm{~cm}\end{array}$ & $2^{\text {nd }}$ attempt \\
\hline 8 & $M$ & 28 & $\begin{array}{l}\text { Fever } 6 \text { days, } \\
\text { diarrhea } 2 \\
\text { days }\end{array}$ & 39.1 & neg & $\begin{array}{l}3400 \\
(N 25 \text { L } 61 \\
\text { Mo 13) }\end{array}$ & - & $\begin{array}{l}\text { Hepatic } \\
\text { flexure } \\
2.3 \mathrm{~cm}\end{array}$ & $2^{\text {nd }}$ attempt \\
\hline 9 & $\mathrm{~F}$ & 8 & $\begin{array}{l}\text { Fever + bloody } \\
\text { stool } 2 \text { days }\end{array}$ & 36 & $\begin{array}{l}\mathrm{RLQ} \\
\text { mass }\end{array}$ & - & $\begin{array}{l}\text { Unremark- } \\
\text { able }\end{array}$ & $\begin{array}{l}\text { Hepatic } \\
\text { flexure }\end{array}$ & $1^{\text {st }}$ attempt \\
\hline
\end{tabular}

Note : abdominal film - 5 cases in written part, but show only 4 cases in table

\section{Discussion}

There is a wide variation in the techniques of non-surgical reduction of the intussusception ${ }^{7}$. Variation refers in two aspects. The first variation depends on guidance method either fluoroscopy or US. The other variation depends on material used either liquid or gas. Pneumatic reduction under fluoroscopy has become popular nowadays because of higher success rate than barium ${ }^{5,6}$. However it still has radiation hazard. Hydrostatic reduction by saline enema is quite popular in Eastern world ${ }^{2}$. In the large series of Bai $\mathrm{YZ}$ et al. $^{2}$, they reported
UGHSE in 5218 cases and the success rate was $95.5 \%$ with $0.17 \%$ perforation rate. The only disadvantage of US is operator dependent. Thus learning curve is needed to perform with confidence. Newer techniques such as US-guided pneumatic reduction $^{8}$, external manual reduction with US assistance ${ }^{9}$ have been presented recently. The best technique has not been in consensus yet. US criterion for successful reduction were disappearance of the intussusceptions, and fluid reflux into the terminal ileum $^{2}$. We observed that visualization of the IC valve made us more confident in distinguishing between 


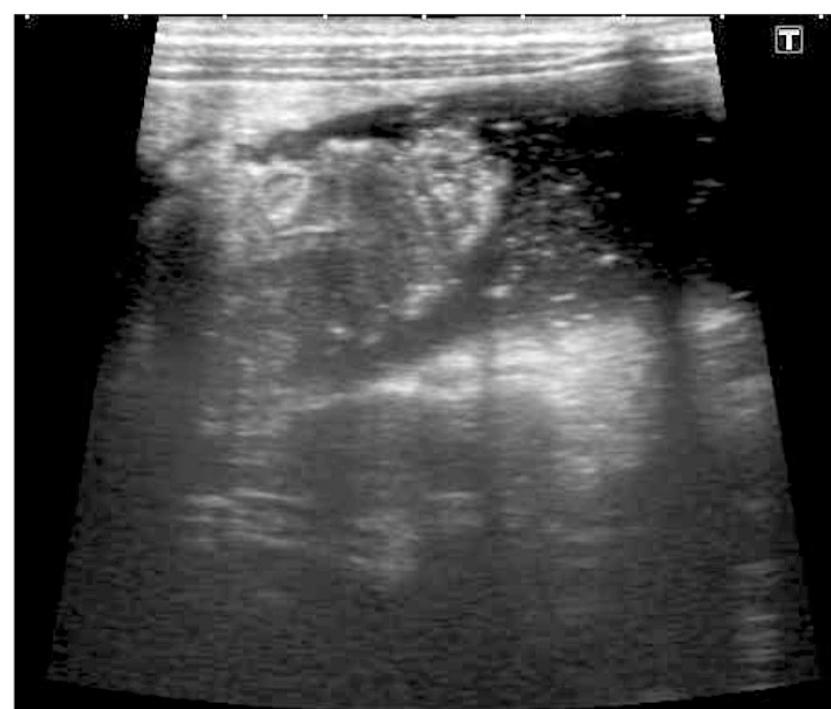

Fig. 1 Normal saline at the apex of intussuception



Fig. 3 Intussusceptum passing IC valve

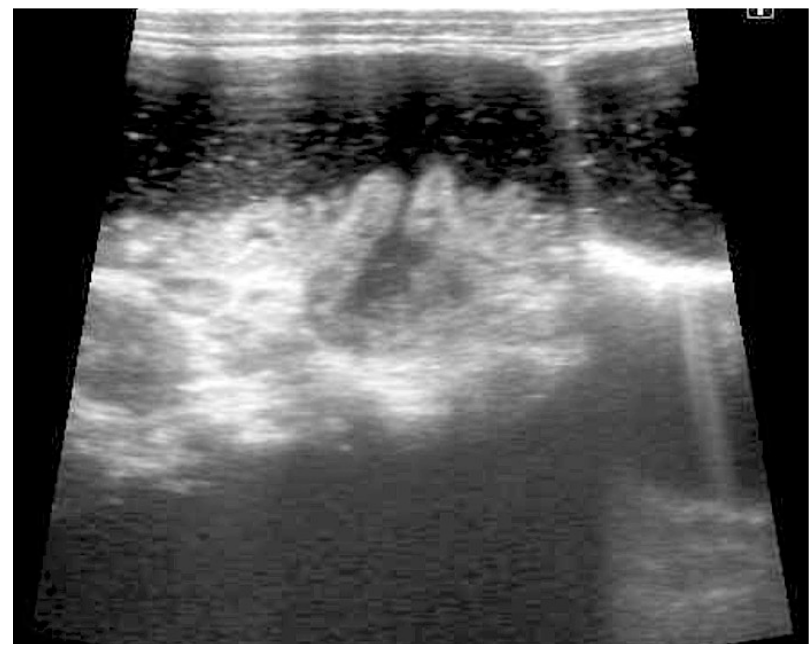

Fig. 5 IC valve post reduction



Fig. 2 Intussusceptum at IC valve

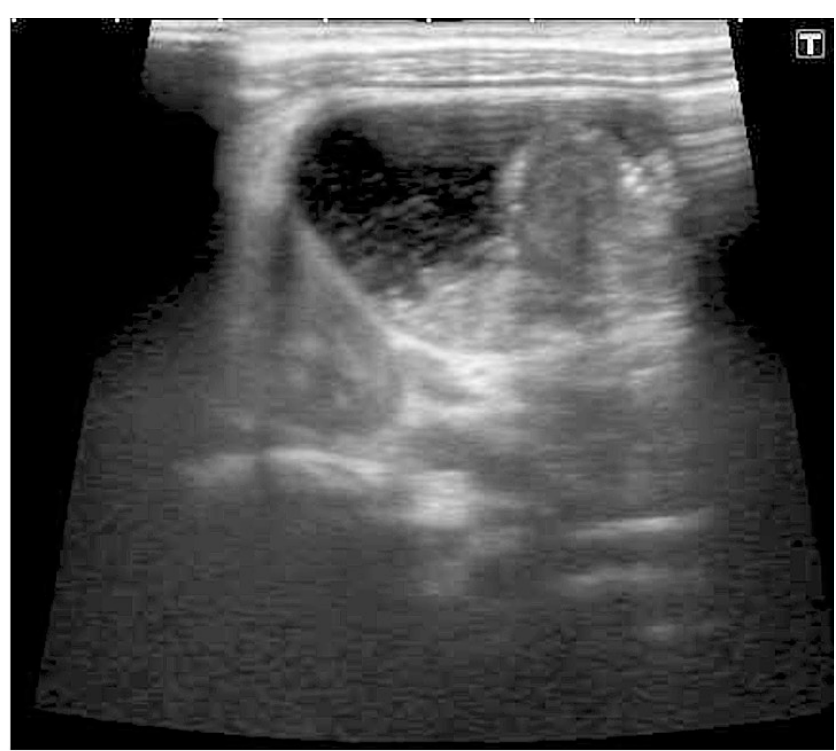

Fig. 4 Intussusceptum almost passed IC valve

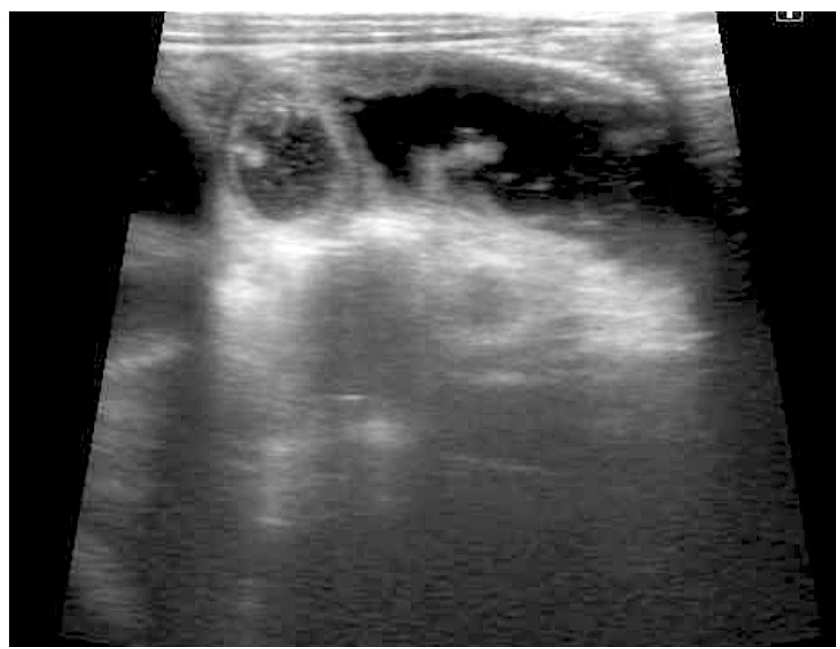

Fig. 6 Swollen terminal ileum with gradual transition to normal wall 
colon and ileal loops. Yoon $\mathrm{CH}$, et al. ${ }^{8}$ proposed the other criteria as abrupt transition between the swollen terminal ileum and the proximal normal ileal loop in long-axis scan could rule out any residual ileoileal intususception.

We did not use any sedation in this our series as well as in the report of 194 cases by GonzalezSpinola, et al. ${ }^{10}$ which showed success rate in almost 90\%. However In the recent report of Ilivitzki A, et al. ${ }^{11}$ claimed that using deep sedation with propofol during reduction of intussusceptions was safe and effective.

\section{Conclusion}

In our 9 case series, UGHSE is feasible with high success rate without complication. The benefit is no radiation which is a point of our concern. We would like to encourage radiologists to perform this technique. If we have enough number of patients, we can generalize the advantages or disadvantages of this technique.

\section{References}

1. Kobayashi Y, ShimiZu N, Matsuda R. Thirty -seven years of experience in the treatment of intussusceptions in infants and children. Yonago Acta Med 1987;30 Suppl: 193-202.

2. Bai YZ, Qu RB, Wang GD, Zhang KR, Li Y, Huang Y, et al. Ultrasound-guided hydrostatic reduction of intussusep- tions by saline enema: a review of 5,218 cases in 17 years. Am J Surg 2006;192:273-5.

3. Hryhorezuk AL, Strouse PJ. Validation of US as a firstline diagnostic test for assessment of pediatric ileocolic intussusceptions. Pediatr Radiol 2009;39(1):1075-9.

4. Chan KL, Saing HS, Peh WC, Mya GH, Cheng W, Khong $\mathrm{PL}$, et al. Childhood intussusceptions: ultrasound-guided Hartmann's solution hydrostatic reduction or barium enema reduction? J Pediatr Surg 1997;32(1):3-6.

5. Hannon EJ, Allan RA, Negus AS, Murphey F, Okoye BO. Air enema reduction of intussuception: a registrar-led, protocol driven service is safe and effective. Pediatr Surg Int 2013;29:805-9.

6. Hadidi AT, Shal NE. Childhood intussusceptions: a comparative study of non surgical management. J Pediatr Surg 1999;34(2):304-7.

7. Rosenfeld K, McHugh K. Survey of intussusceptions reduction in England, Scotland and Wales: how and why we could do better.Clinical Radiology 1999;54:452-8.

8. Yoon HC, Kim HJ, Goo HW. Intussusception in children: US-guided pneumatic reduction-initial experience. Radiology 2001;218:85-8.

9. Vazquez JL, Ortiz M, Doniz MC, Monterio M, Campo VM. External manual reduction of paediatric idiopathic ileocolic intussusceptions with US assistance: a new, standardized, effective and safe manoeuvre. Pediatr Radiol 2012;42:1197-204.

10. Gonzalez-Spinola J, Pozo GD, Tejedor D, Blanco A. Intussuception: the accuracy of US-guided saline enema and the usefulness of a delayed attempt at reduction. J Pediatr Surg 1999;34(6):1016-20.

11. Ilivitzki A, Shtark LG, Arish K, Engel A. Deep sedation during pneumatic reduction of intussusceptions. Pediatr Radiol 2012;42:562-5. 